\title{
National Failure: Social Studies Education to the Rescue
}

\author{
Dr. Fasiku, Adesola Mercy \\ Department of Social Studies, College of Education, Ikere Ekiti, Ekiti State Nigeria

\section{Abstract} \\ The benefits of Social Studies as an interdisciplinary problem solving discipline in our national curriculum can \\ never be overemphasized. The concept touches all aspects of societal development such as political, economical, \\ social, cultural, technological and educational aspects. The core of the subject is the preparation of individuals \\ to contribute immensely to the development of the nation effectively and the transmission of the social and \\ cultural values to new generation. Despite the important position that education occupies in the country, the \\ society is still surrounded by array of problems such as kidnapping, religion intolerance, lack of credible \\ elections, insecurity, dishonesty, corruption, human trafficking, raping, inequality in the distribution of common \\ wealth among others. All these and many more combine to threaten the advancement of Nigeria on daily basis \\ and if nothing is done to avert it, it will lead to total collapse of this great Nation. In this paper, attempt was \\ made to explain some basic concepts and examine some challenges threatening the oneness of Nigeria as a \\ sovereign State. The paper also exposed the roles Social Studies plays in averting National failure. It also \\ suggested practical steps to be taken to confront the numerous challenges threatening the oneness of Nigeria as \\ a sovereign State. Finally, it suggested ways by which Social Studies teachers can be more proactive and \\ effective in the teaching of the subject.
}

Keywords: Social Studies Education, Rescue, National challenges, Social Studies Teacher

DOI: $10.7176 /$ RHSS/9-22-08

Publication date: November $30^{\text {th }} 2019$

\section{Introduction}

Nigeria as a developing nation is presently sitting on a keg of gun powder which can explode at any time. This country is far behind developed countries, especially in the field of social conduct. Moral values, Political tussles, economical problems, and social crises are extremely common and have become critical issues challenging Nigerian society. For this reason, Nigeria needs distinguished, qualified, and informed citizens who possess relevant skills, norms and knowledge to salvage the country from its social, economic, cultural and political crises. In this respect, Nduka (2004) affirmed that the pervasive influence of value disorientation seriously challenges Nigerian individuals and communities. Despite the level of her education, Nigeria is still found wanting morally, economically, socially, and politically. These social problems can be found at the local, state, national, and international levels of government. In order to avert these problems, an effective approach to deliver the nation from these moral decay and promote the growth and development of Nigerian society is no other means than to restore the Nigerian educational system. The only antidote to accomplish this is through Social Studies education.

Social Studies was integrated into the Nigerian school curriculum to rescue Nigerians from all sort of social vices and to encourage them towards becoming good citizens who would help the country realize her national goals and objectives (Obidoa, 1991; CESAC, 1993; Gabriel, 2008; Gbenga, 2001; Ogunsanya, 1984, Woolman, 2001). Social Studies is the study of man in relation to his physical and social environment with a corrective measure that is designed to proffer solution to man's problems in a holistic form. It is on this note that this paper presents the concept of Social Studies, highlights the national educational goals, objectives of Social Studies, some social problems in Nigeria, roles of Social Studies to rescue Nigeria from her various challenges to avoid National failure, challenges facing the subject in realizing its objectives and finally presents some suggestions for dealing with the problems.

\section{Concept of Social Studies}

Social Studies as a problem solving subject started from America and Europe after the World War II.It was later introduced into Nigeria curriculum before the independence and was finally tested at Aiyetoro comprehensive High School (Oladele , 2015) in its quest to construct a better and ideal society to assuage the feeling of the people, the great suffering and destruction experienced during the wars, Social Studies was finally introduced into the school curriculum with a view to giving children relevant liberal education that would provide greater understanding of mankind and also make them to become socially conscious and responsible members of the society. The term Social Studies has been defined differently by different commission, committees and authors. 
National Education Research and Development Council (NERDC) (1971) sees Social Studies as the study of man and his interactions with his social and physical environments. It can therefore be defined as the area of the study made up of selections from other subjects which has to do with the art of living together peacefully in our family, community and society (Oladele, 2015).

Uboh (1984) views Social Studies as the study of man and the outcomes of his relationship and interactions with his environments. Kissock (1981) defines Social Studies as a programme of instruction which the society uses to instill in students the skill, knowledge, values, attitude and actions considered important concerning the relationship human beings has with each other, their world and themselves. Orakwue (1991) defines Social Studies as the study of man in his unending interactions with his environments as he attempts to make them a better place. The definition of Social Studies is not limited to the above definitions but, it is expedient to note that it centers on man, human behaviors and interactions within specified environments. A child that is well prepared for the future will definitely add value to his society in adulthood.

\section{Challenges Inhibiting the Advancement of Nigeria As A Nation}

Virtually, every part of this country is bedeviled with one problem or the other, the problem of Boko Haram is threatening the peace of the North East, banditry is a daily occurrence in the North West, herdsmen problem in the North Central, kidnapping in the South East, pipeline vandalization in the South South, ritual and merciless killings in the Southwest. Added to the aforementioned are the cultural pressure groups in each zone agitating for autonomy. All these challenges and many more combine to threaten the existence of Nigeria on daily basis. They precipitated instability, mistrust, mutual suspicion to propel the economy on the backward trend. The case of unemployment is on the increase thereby enthroning poverty and lack of National development. Ajibewa (2008) listed some social, economical, and political crises in Nigeria as follows: Corruption, Poverty, Unemployment, Electoral fraud, Crime and Insecurity, agitation for zone independence, andLeadership Crisis. The founding fathers of this country did not envisage what is currently happening in this country but thought of a virile, prosperous and strong country among the comity of nations. The spate of uncomplimentary events besetting Nigeria/Nigerians on daily basis, if not checked will hasten the total collapse of this country and dash the hope of our founding fathers. It is therefore important for this country to remain united and successful, necessary knowledge and information must be imparted now and which must be improved upon and passed to the future generation.

\section{Social Studies Education to the Rescue}

Education, either formal or informal is the fulfilling of our endowed intellectual capacities. It is generally perceived to be the process of discipline through training and study in the acquisition of skills and knowledge. According to Awopetu, Fasiku and Daramola (2013) Education means the training of the entire person to enable him make himself fit for living in a society.

Social Studies experts as well as educationists believe strongly that the transformation of people's behaviour before they attain adulthood is the business of the school. Ezema (2001) underscores the role of the school as a very vital agent of socialization and provision of the appropriate curriculum and approaches for prompt moral cultivation and transformation as follows;

"It is true that the schools do not participate directly in social change, they necessarily assume the task of preparing children for adult citizenship that involves such participation. They surely can lay the intellectual foundation for an understanding of what democracy means and what it demands of its citizens. One of the most urgent requirements of democracy is the subordination of selfish and narrow loyalties to personal or group interests to the wider loyalties of national development in all its parameters. Through content and teaching procedures, schools can educate the pupils in competent citizenship. For effecting change in the human sector, training on the right lines must be given in the formative period of life." (Kocchar, 2012)

Flowing from the above, it is settled that Social Studies is elastic enough to proffer solution and avert National failure. National goals of Education policy and Social Studies objectives could be well subsumed in the above quotation and attack each of the challenges if well taught at the various levels of our institutions.

Ezema (2001) particularly noted that with Social Studies Education, citizens are able to -

"Appreciate the diversity and interdependence of members of different communities the world over ... to appreciate the need for co- operation, justices, fair play, tolerance, honesty and patience, all of which are indispensable for the wellbeing, progress and general development of every human community."

The import of social studies is well captured in both the National Educational Goals and the objectives of social studies. 


\section{The National Educational Goals}

As stated in the National Policy on Education (FGN, NPE, 2004) the National Philosophy of Education for Nigeria is based on the integration of an individual into a sound and effective citizen with equal opportunities for all citizens. Stemming from the National Philosophy are the goals of education which are:

* The inculcation of national consciousness and national unity,

* The inculcation of the right type of values and attitudes for the survival of the individual and the nation,

* Training of the mind in the understanding of the world around, and

* The acquisition of appropriate skills, and the development of mental, physical and social abilities and competencies as equipment for the development of the society.

\section{Objectives of Social Studies}

The general objectives of Social Studies education are derived from the broad national goals of education. Therefore, the goals of Social Studies education are to:

* Create awareness and an understanding of our evolving social and physical environment as a whole, in its natural, man - made, cultural and spiritual resources together with the rational use and conservation of these resources for national development. Understanding of one's environment is very important. Contribution in whatever facet becomes acceptable once it is done in compliance with prevailing culture, norms and values. This will build cohesion and ensure stability of Nigeria.

* Develop in the child a capacity to learn and to acquire certain basic skills including not only those of listening, speaking, reading and writing, and of calculation but also those skills of hand and head, together with skills of observation, analysis and inference which are essential to the forming of sound social, economic and political judgment; An idle hand is the devil's workshop but when one is gainfully employed, it will be difficult for him to engage in actions that can cause failure of a society. The youth that are being pushed around today are vulnerable primarily because they are unemployed but when they acquire one skill or the other there will be concentration in whatever they are doing without giving room to think on anything that can cause the failure of the society.

* Ensure the acquisition of that body of knowledge and information which are essential pre - requisite for personal development as well as personal contribution to the betterment of mankind. Knowledge is power, a man who is knowledgeable can never be a push over.People that are involved in some of the nefarious activities that are inimical to the advancement of the society have fail to ensure their personal development because of lack of pre - requisite knowledge and information. There are so many things that would not happen in the society if people are abreast with the needed information. Intelligent gathering through institutions saddled with the responsibility and availability of it to the populace is very vital.

* Develop a sympathetic appreciation of the diversity and interdependence of all members of the local community, and the wider national and international community; Asa society that is wrapped up in diversity, Nigeria must give room for the voice of every sectionto be heard and appreciated. People should be free to live anywhere and be acculturated.This will open ways for the needed integration of the society called Nigeria.

* Develop positive attitudes of togetherness, comradeship and cooperation towards a healthy nation, the inculcation of appropriate values of honesty, integrity, hard work, fairness and fair play as one's contribution to the development of the national goals. Schemes and policies anchored by strong institutional frame work to ensure that people shun what is bad and place premium on virtues that can sustain the spirit of togetherness must be a priority (Akinlaye, Mansaray and Ajiboye, 1996).

It is believed that when positive attitudes, values, beliefs and love for one another and the awareness of our physical, cultural, religious, ethnicity and social environment are inculcated into the citizens, political, economical, social and cultural vices such as kidnapping, religion intolerance, lack of credible election, insecurity, dishonesty, corruption, human trafficking, raping, inequality in the distribution of common wealth among others will be averted in our dear nation, Nigeria (Okam 1988).

\section{Who should teach the Social Studies Education?}

Social Studies teacher occupies a central position in the issue under this discourse. Though there is much emphasis on the pupil - centered education, it is still a fact that it is the responsibility of the teacher who is 
expected to make the subject lively, interesting and useful. It is the teacher that can inspire and guide the pupils and students and also create the climate and atmosphere in which training for democratic citizenship becomes possible (Kochhar, 2012).

The Social Studies teacher should therefore be well-equipped with academic qualifications; an expert in the methodology of teaching Social Studies, a scientist as well an artist; breadth of outlook and width of understanding; a person of integrity; a person of sound professional ethics; an interesting person; a good citizen; widely travelled; a man of faith; and a person who grows professionally.

\section{Conclusion}

The National Philosophy of Education policy is well articulated and framed with a view to having citizens that are responsible and responsive to issues toward securing a strong, virile, prosperous and developed Nigeria. The vehicle for awareness and the information for the right attitude to make the policy materialized is well located in Social Studies Education. This presupposes that the handlers both teachers and policy makers of Social Studies Education must be professionally qualified, committed, passionate, well exposed to imbibe the right attitude and information during the teaching of the subject at all levels.

\section{Recommendations}

1. There is the need for continuity. The curriculum of Social Studies which ends at JSS III should be a continuous programme that will extend to senior secondary level.

2. Government should encourage small scale industries through granting of loans without interests to the people at grassroots which will serve as empowerment. This will keep them busy and make them lose interest in crimes once they are gainfully employed.

3. The government should allow the judiciary to be independent to perform its duties without interference. If criminals are punished without delay and political patronage avoided, people will be secured and deterred from committing crimes.

4. The Local, State, Federal government as well as individuals should give the electoral commission free hand to operate. The much requested Election Offences Tribunal must be established. This will help to curb the rate of thuggery, kidnapping, assassination, abuse of power, rigging of election etc.

5. It is urgently imperative to change the direction which Nigerian society is drifting by clarifying those core social values that held the pre-colonial society and apply them accordingly in all ramifications and as well infuse such values in the nation's modern leadership styles.

6. Strong Institutions are undoubtedly considered to be the custodians of the societal values by placing limits to people's behavior (regardless of status or class). Therefore, strengthening and empowering our institutions to their full capacity becomes imperative. These institutions must be rooted and their operations be guided by the principles of rule of law.

\section{References}

Ajibewa, A. (2008). Democracy and Corruption in Nigeria in Ojo, O. O. (ed) Challenges of Sustainable Democracy in Nigeria. Ibadan: John Archers ltd.

Akinlaye, A. F., Mansary, A. and Ajiboye, J. O. (1996). Fundamentals of Social Studies Teaching. Ikeja: Pumark Nigeria limited.

Awopetu, L.O., Fasiku, M.A. \& Daramola, C.O. (2013).Research methods and statistics in Social Science. Ado: Greenline Publisher.

CESAC Comparative Education Studies and Adaptation Centre (1993), NigerianSecondary Schools Social Studies Project Book 1, Lagos: $\quad$ NERDC.

Ezema, M. C. (2001). The Importance of Social Studies for citizenship Education in Nigeria in Ofuebe, C. (Ed.) Dynamics of Social Studies, Enugu: New Generation Books

Federal Government of Nigeria (2004). National Policy on Education, Lagos: NERDCJournal of Economics and Sustainable Development www.iiste.orgISSN 2222-2855 (Online) Vol.4, No.2, 2013 Retrieved on $23 / 08 / 2018$

Gabriel, T. O. (2008). Social Studies Teacher as a Role Model in Achieving Value Regeneration. Nigerian Journal of Social Studies 11 (1).

Gbenga, R. (2001). Toward Effective Social Studies in Nigerian Schools, Education. Review, 134(1) 56-68.

Kissock, C. (1981). Curriculum Planning in Social Studies Across Cultural Approach.Zaria: John Willey and Sons. 
Kochhar, S. K. (2012). The Teaching of Social Studies. India: Sterling Publishers Private Limited

National Policy on Education, NPE (2004). Published by Nigerian Educational Development Council, Lagos, Nigerian.

NigerianStates, African Institute for Applied Economics, Becans Working Paper 1.

Obidoa, A. (1991). A re-appraisal of liberal arts and Social Studies Education in Nigerian schools in national secondary school curriculum review conference proceedings, Ibadan: Macmillan Nigeria Publishers Limited. 197-202.

Ogunsanya, M. (1984). Introduction to Methodology of Social Studies, Ibadan: Evans.

Okam, C. C. (1988).Students-teachers' perception of the Social Studies programme for Teachers' Grade II in Nigeria. Unpublished Ph.D Thesis, Faculty of Education, University of Jos.

Oladele, O. (2015). Social Studies for Upper Levels 7 - 9. Ibadan: Holad Publisher

Orakwe, I.T.C. (1991). Social Studies (Education Basics) for Tertiary Institutions. Onitsha: DESVIC Publishers.

Ujah, O. and Eboh, E. (2006).The Security Factor in Business Environment Across

Wooliman, D. C. (2001). Educational reconstruction and post-colonial Curriculum Development: A Comparative Study of four African Countries. International Education Journal 2 (5), 27 - 46. 